\title{
NVMO-congres 2000
}

Het tiende Gezond Onderwijs Congres van de Nederlandse Vereniging voor Medisch Onderwijs (NVMO) vond plaats op 30 november en 1 december 2000 in het Golden Tulip Conference Hotel Koningshof in Veldhoven. Net als in het jaar ervoor namen meer dan 400 deelnemers uit Nederland en België aan het congres deel. De hoofdorganisatie werd verzorgd vanuit het Onderwijscentrum Inwendige Geneeskunde van het Leids Universitair Medisch Centrum.

De drie plenaire hoofdlezingen in het programma hadden betrekking op drie actuele ontwikkelingen binnen het medisch onderwijs in Nederland en Vlaanderen. Allereerst besprak mevrouw prof. dr. M. Boekaerts de consequenties die de curriculumwijzigingen in het voorbereidend wetenschappelijk onderwijs in Nederlands hebben voor de aansluiting met de diverse opleidingen op het gebied van de gezondheidszorg. Vervolgens presenteerde prof. dr. P. Coetsier ervaringen met een toelatingsproef voor geneeskunde- en tandheelkundestudenten in Vlaanderen. En tot slot ging prof. drs. O. Hokwerda nader in op het 'consilium abeundi', het bindend studieadvies waarmee het mogelijk is om studenten in de loop van hun studie alsnog op basis van weloverwogen argumenten dwingend te adviseren de studie voortijdig te beëindigen. Naast deze drie hoofdsprekers waren op uitnodiging van de congresorganisatie drie experts gevraagd om een actueel overzicht te geven van de stand van zaken op hun eigen medisch-onderwijskundig onderzoeksterrein. In deze sessies ging dr. P. Ram nader in op het onderwerp toetsing in de echte praktijk (in vivo), besprak dr. R. Remmen de mogelijkheden en beperkingen van een transversale kwaliteitscontrole in het onderwijs en ging dr. Y. Vermetten dieper in op het gebruik van leerstijlen en deskundig studeren. Dit nummer van het Tijdschrift voor Medisch Onderwijs (TMO) bevat uitgebreide artikelen naar aanleiding van drie van bovengenoemde plenaire lezingen op het NVMO-congres.

Naast de plenaire lezingen waren er acht workshops, discussiesessies en een kleine honderd paperpresentaties. Vanuit de studentenorganisatie werd een succesvolle paneldiscussie georganiseerd over de verschoolsing van de artsopleiding en de Werkgroep Computer Ondersteund Onderwijs (COO) verzorgde ook dit jaar weer een aantal geslaagde COO-demonstraties.

In navolging van 1999 werden ook in 2000 prijzen uitgereikt voor de beste bijdrage in de categorie beschrijvend en de beste bijdrage in de categorie onderzoek. Een jury bestaande uit prof. dr. A.G.M. Derese, drs. H.L. Hendrix en dr. A.M.J.J. Verweij heeft tien genomineerde abstracts beoordeeld en de bijbehorende presentaties bezocht. De tabel geeft een overzicht van de genomineerde abstracts. De beoordeling leidde uiteindelijk tot twee prijswinnaars: A. Bruining (student uit Maastricht) en L.C. Aukes (docent uit Groningen). Beide winnende abstracts zijn in dit nummer van TMO opgenomen. 


\begin{tabular}{|l|l|}
\hline \multicolumn{2}{|l|}{ Genomineerden voor de prijzen op GOC2000 } \\
\hline Categorie beschrijvend & Categorie onderzoek \\
\hline $\begin{array}{l}\text { Hoogenboom JM, Bais AG, Bonke B, Bootsma AH, } \\
\text { Spaai GWG } \\
\text { Begeleiding naar professioneel gedrag }\end{array}$ & $\begin{array}{l}\text { Pols J, Cohen-Schotanus J } \\
\text { Artsen hebben bij contacten met chronisch zieken } \\
\text { last van lacunes in hun studie }\end{array}$ \\
\hline $\begin{array}{l}\text { Aukes LC } \\
\text { Professioneel gedrag: een (on)mogelijke opgave } \\
\text { voor studenten/artsen? }\end{array}$ & $\begin{array}{l}\text { Agsteribbe J, Cohen-Schotanus J } \\
\text { Stress onder artsen }\end{array}$ \\
\hline $\begin{array}{l}\text { Nieuwhof MGH, Cate ThJ ten, Vermunt JD } \\
\text { Inhoudsconceptie en de betekenis voor het } \\
\text { studieproces }\end{array}$ & $\begin{array}{l}\text { Hylkema N, Prince CJAH, Mameren H van, } \\
\text { Scherpbier AJJA, Vleuten CPM van der, Drukker J } \\
\text { Klinisch relevante anatomiekennis van vierdejaars } \\
\text { studenten geneeskunde in Nederland }\end{array}$ \\
\hline $\begin{array}{l}\text { Locher G, Rhijn SM van } \\
\text { Feedback tijdens blok I in de huisartsopleiding }\end{array}$ & $\begin{array}{l}\text { Haes JCJM, Oort FJ } \\
\text { Betrouwbaarheid en validiteit van de Amsterdamse } \\
\text { Attitude en Communicatie Schaal }\end{array}$ \\
\hline $\begin{array}{l}\text { Oderwald AK, Essed GGM, Sundström P, Oussager J } \\
\text { Het meten en het beoordelen van (de ontwik- } \\
\text { keling van) morele sensitiviteit en vaardigheden }\end{array}$ & $\begin{array}{l}\text { Bruining A, Verheggen MM, Schuwirth LWT } \\
\text { Een beter inzicht in de aard van het cueing-effect }\end{array}$ \\
\hline
\end{tabular}

Het bestuur van de NVMO en de organiserende werkgroep hopen dat de lezers van TMO door dit speciale congresnummer geïnspireerd worden om ook dit jaar het NVMO-congres te bezoeken. Het congres zal plaatsvinden op donderdag 22 en vrijdag 23 november 2001, in Veldhoven.

Werkgroep GOC2000 (tevens gastredactie van dit nummer van TMO)

Dr. ir. P.G.M. de Jong (hoofdorganisator, Leids Universitair Medisch Centrum)

Dr. R. Remmen (Universiteit Antwerpen) Mw. dr. D.H.J.M. Dolmans (Universiteit Maastricht)
Mw. drs. C.R.M.G. Fluit (Universitair Medisch Centrum St Radboud Nijmegen) Mw. M. Sterman-Vleeschdraager (NVMO)

Nadere informatie over het NVMO-congres 2001 is te verkrijgen bij:

Kongresservice Brabant, Postbus 141, 5500 AC Veldhoven

Telefoonnummer : 040-258 1820, faxnummer: 040-254 6566

E-mail: congres@nvmo.nl

Namens de gastredactie

Dr. ir. P.G.M. de Jong, hoofdorganisator 